\title{
ANÁLISE DAS CARACTERÍSTICAS DE UMA JUNTA SOLDADA, DE UM AÇO INOXIDÁVEL DUPLEX, COM E SEM TRATAMENTOS TÉRMICOS
}

\author{
ANALYSIS OF THE CHARACTERISTICS OF A WELDED JOINT, A DUPLEX \\ STAINLESS STEEL, WITH AND WITHOUT HEAT TREATMENTS
}

\author{
Alessandro Fraga Farah ${ }^{\mathrm{I}}$ \\ Márcia Aparecida Gomes ${ }^{\text {II }}$ \\ Solange Pereira dos Santos Farah ${ }^{\text {III }}$ \\ Marcelo Caetano Junior ${ }^{\text {IV }}$ \\ Thiago Teixeira Batistela ${ }^{\mathrm{V}}$
}

\begin{abstract}
RESUMO
Analisou-se uma amostra de aço inoxidável Duplex UNS 31803, soldada com eletrodos do tipo E309Mol, e tratada termicamente em diferentes situações de aquecimento e resfriamento, e também, sem qualquer tipo de tratamento para avaliar a influência na microestrutura e microdureza. Foram selecionadas três amostras das juntas soldadas, sendo que uma amostra foi tratada a $600^{\circ} \mathrm{C}$ por duas horas e resfriada ao ar, outra amostra foi tratada a $1050^{\circ} \mathrm{C}$ por duas horas resfriado em água e aquecido novamente a $600^{\circ} \mathrm{C}$ por duas horas e resfriado ao ar e uma amostra não passou por tratamento térmico. Realizou-se análise metalográfica por microscopia óptica e ensaio de microdureza Vickers. Observou-se que para o tratamento térmico a $600^{\circ} \mathrm{C}$ houve variações significativas na microestrutura e microdureza. Para o tratamento térmico a $1050^{\circ} \mathrm{C}$ houve uma homogeneização na microestrutura e apresentou variação significativa na dureza da zona fundida (ZF). Concluiu-se que os tratamentos térmicos promoveram diminuição na dureza da zona fundida e na zona termicamente afetada pelo calor (ZTA) do aço inoxidável Duplex UNS 31803.
\end{abstract}

Palavras-chave: Aço Inoxidável. Duplex. Soldagem. Tratamento Térmico.

\begin{abstract}
A sample of Duplex UNS 31803 stainless steel, welded with E309Mol electrodes, and heat treated in different heating and cooling situations, and without any treatment to evaluate the influence on microstructure and microhardness was analyzed. Three samples of welded joints were selected, one sample being treated at $600^{\circ} \mathrm{C}$ for two hours and cooled in air, a sample

I Prof. Dr. da Faculdade de Tecnologia (FATEC) de Sertãozinho - São Paulo - Brasil. E-mail: alessandro.farah@fatec.sp.gov.br

II Profa. Me. da Faculdade de Tecnologia (FATEC) de Sertãozinho - São Paulo - Brasil. E-mail: marcia.gomes@fatec.sp.gov.br

III Profa. Me. da Faculdade de Tecnologia (FATEC) de Sertãozinho - São Paulo - Brasil. E-mail: solange.farah@fatec.sp.gov.br

${ }^{\text {IV }}$ Estudante do Curso Superior de Tecnologia em Manutenção Industrial da Faculdade de Tecnologia (FATEC) de Sertãozinho - São Paulo - Brasil. E-mail: marcelocaetano.jr@ hotmail.com

${ }^{v}$ Estudante do Curso Superior de Tecnologia em Manutenção Industrial da Faculdade de Tecnologia (FATEC) de Sertãozinho - São Paulo - Brasil. E-mail: tet.batistela@gmail.com
\end{abstract}




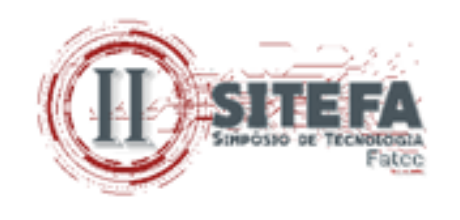

was treated at $1050^{\circ} \mathrm{C}$ for two hours cooled in water and heated again at $600^{\circ} \mathrm{C}$ for two hours and air-cooled and a sample was not thermally treated. Metallographic analysis was performed by optical microscopy and Vickers microhardness assay. It was observed that for the thermal treatment at $600^{\circ} \mathrm{C}$ there were significant variations in the microstructure and microhardness. For the heat treatment at $1050^{\circ} \mathrm{C}$ there was a homogenization in the microstructure and presented significant variation in the hardness of the molten zone (ZF). It was concluded that the thermal treatments promoted a decrease in the hardness of the melt zone and in the heat-affected zone (ZTA) of Duplex stainless steel UNS 31803.

Keywords: Stainless steel. Duplex. Heat treatment.

Data de submissão do artigo: 15/07/2019.

Data de aprovação do artigo: 01/10/2019.

DOI:

\section{INTRODUÇÃO}

Os aços inoxidáveis são ligas de ferro-cromo, resistentes a corrosão e ao calor contendo no minimo $11 \%$ de cromo. Apesar de outros metais atuarem como elementos de liga, o mais importante, é o cromo para conferir a resistência a corrosão desejada. Nestes aços não ocorre oxidação em ambientes normais. Suas características de resistência são obtidas graças à formação de um óxido protetor que impede o contato do metal-base com a atmosfera agressiva. Hoje, podemos observar inúmeras aplicações do aço inoxidável como, por exemplo, em eletrodomésticos, automóveis, ônibus, vagões ferroviários, em fachadas, elevadores, escadas rolantes, equipamentos hospitalares, bens de capital e na indústria em geral. A especificação correta do aço deve sempre considerar a aplicação final do produto, o projeto e o processo de fabricação. Há uma grande variedade de aços inoxidáveis com níveis progressivamente maiores de resistência à corrosão e resistência mecânica. Isso é resultado da adição controlada de elementos de liga, cada um deles originando atributos específicos com relação a resistência mecânica e possibilidade de resistir a diferentes meios ambientes. Em condições de serviço a altas temperaturas ou quando expostos a operações de soldagem, várias fases podem se precipitar na microestrutura dos aços inoxidáveis, provocando modificações das suas propriedades. Visando diminuir a precipitação de fases indesejáveis podem ser empregados tratamentos térmicos pós-soldagem. O presente trabalho tem como objetivo avaliar a influência dos diferentes tipos de tratamentos térmicos feitos após a soldagem, avaliando assim o que ocorrerá com a microestrutura e propriedades mecânicas do aço inoxidável. Analisou-se amostras de aço inoxidável Duplex UNS 31803, soldadas com eletrodo do tipo E309Mol, com aplicação de tratamento térmico em diferentes situações de resfriamento e aquecimento e também sem a presença de qualquer tipo de tratamento. Avaliou-se as amostras por meio de ensaios de microdureza e microscopia ótica.

\section{AÇOS INOXIDÁVEIS}

Os aços inoxidáveis são aços de alta liga, geralmente contendo cromo, entre outros elementos, em sua composição química, que, conforme denominação, não se oxida em contato com agentes corrosivos. São materiais com utilizações crescentes nas indústrias em função de suas características específicas, principalmente aquelas relacionadas à resistência a 


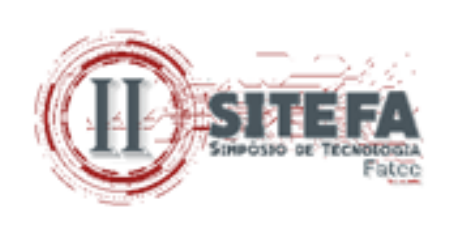

corrosão e às propriedades mecânicas. Porém são materiais que exigem cuidados especiais na sua fabricação sob o risco de comprometimento de suas propriedades (SILVA, 2011).

\subsection{Tipos de Aços Inoxidáveis}

Os tipos de aço inoxidável podem ser classificados, segundo Anschau (2009), em cinco famílias básicas: Austeníticos, Ferríticos, Martensíticos, Endurecíveis por precipitação e Duplex.

Os Austeníticos têm a estrutura cúbica de face centrada. Através dos elementos de austenitização, como manganês, nitrogênio e níquel esta estrutura é obtida. Esse tipo de aço é essencialmente não magnético. O teor de cromo varia geralmente de $16 \%$ a $26 \%$ e de níquel até $35 \%$. Podem ser adicionados outros elementos para melhorar certas características como resistência a oxidação ou resistência a corrosão por pites (LOUREIRO, 2010). Eles apresentam boa ductilidade, possuem boa soldabilidade e tenacidade em temperaturas baixas enquanto sua resistência à corrosão sob tensão e sua resistência mecânica são baixas, mas, no entanto, principalmente ao níquel adicionado apresentam alto custo. As indústrias químicas e petroquímicas utilizam muito o aço inoxidável austenítico devido a essas propriedades (LOUREIRO, 2010).

Os Ferríticos, segundo Loureiro (2010) possuem estrutura cúbica de corpo centrado e contém principalmente elementos estabilizadores de ferrita, como o cromo. $\mathrm{O}$ teor de cromo está entre a faixa de $11 \%$ a $30 \%$, podendo conter outros elementos para conseguir características únicas. Diferente dos austeníticos, ligas ferríticas são ferromagnéticas, podem ter boa conformabilidade e ductilidade, já em baixa temperatura sua tenacidade pode ser limitada, devido ao alto teor de cromo. O carbono e o nitrogênio são um dos grandes responsáveis pela maioria dos casos da fragilidade das ligas ferríticas, mas podendo também surgirem de diversas outras causas. Esses aços são imunes a corrosão sob tensão e normalmente possuem um baixo custo (LOUREIRO, 2010).

Os Martensíticos possuem uma estrutura distorcida cúbica de corpo centrado e são essencialmente de ligas de cromo e carbono. Também são ferromagnéticos, geralmente são resistentes a corrosão e são endurecíveis por tratamento térmico. O teor de cromo está geralmente entre a faixa de $11 \%$ a $18 \%$ e o teor de carbono não pode ultrapassar $1,2 \%$. Para assegurar uma estrutura martensítica após o endurecimento, essas quantias são balanceadas (LOUREIRO, 2010).

Os Endurecíveis por Precipitação, segundo Loureiro (2010), podem ser semiausteníticos, austeníticos ou martensíticos na condição recozida. São ligas de cromo-níquel que contém elementos endurecíveis por precipitação, como alumínio, titânio ou cobre. Dependendo do tratamento térmico, tem boa tenacidade e ductilidade (LOUREIRO, 2010) Sua resistência à corrosão é comparável ao aço austenítico, sua soldabilidade e melhor do que a dos aços martensíticos comuns. São utilizados principalmente em aplicações aeroespaciais (UBINOX, 2018).

Os Duplex têm como característica um comportamento superplástico, que é indicado pelas deformações uniformes às quais pode ser sujeito sem a formação de estricção. Esta superplasticidade estrutural é causada pela presença de uma estrutura muito refinada, que obtida é durante a transformação de parte da fase ferrítica para a combinação de estrutura austenítica/ferrítica. (UBINOX, 2018). O material se mostra interessante, pois apresenta em suas propriedades mecânicas, excelentes limites de resistência à tração e de escoamento, além de excelente alongamento (UBINOX, 2018). 


\subsection{Características dos Aços Inoxidáveis Duplex}

Os Aços Inoxidáveis Duplex (AID) surgiram quando houve a necessidade da utilização em situações que eram exigidas uma boa resistência à corrosão, resistência mecânica, ductilidade, alta tenacidade e ductilidade, combinando assim as qualidades dos aços ferríticos e austeníticos (MAGNABOSCO, 2001).

A proporção considerada ideal nos AID é de 1:1. Porem existem alguns elementos que tem a capacidade de aumentar o campo de estabilidade da ferrita no diagrama de fases $\mathrm{Fe}-\mathrm{C}$, alguns exemplos desses elementos são o silício, o molibdênio e o próprio cromo; e outros elementos atuam como estabilizadores da fase austenita, como níquel, manganês, nitrogênio, cobre e carbono; quando a adição desses elementos são feitas de forma correta, é possível aumentar a resistência a corrosão, assim podendo elevar a estabilização de uma certa fase, proporcionando diferentes comportamentos mecânicos (ANSCHAU, 2009)

Nos processos como tratamentos térmicos e soldagens, que utilizam um fluxo de calor elevado é difícil se manter a proporção das fases de 1:1. Com a maior presença de ferrita a resistência a corrosão do aço diminui (ANSCHAU, 2009)

Os aços inoxidáveis dúplex fazem parte de uma classe de materiais que apresentam uma microestrutura bifásica, composta por uma matriz ferrítica e ilhas de austenita, com frações volumétricas aproximadamente iguais dessas fases. Por apresentarem alto porcentual de elementos de liga, como o cromo, níquel, molibdênio e nitrogênio, o correto é que eles fiquem balanceados em forma apropriada a fim de terem frações volumétrica similares de todas as fases e conceder a ferrita e austenita, consequentemente resistência à corrosão e resistência mecânica (LOUREIRO, 2010).

Os aços inoxidáveis duplex se tornaram essenciais no ramo industrial, considerando sua aplicação no segmento de produtos fundidos, a maior aplicação destes materiais está na fabricação de componentes de bombas centrífugas e válvulas de controle de fluxo. Como estas bombas e válvulas são utilizadas no transporte e posteriormente no controle de fluxo de produtos corrosivos, que são aplicadas em indústrias químicas, petrolíferas, petroquímicas, siderúrgicas, de energia e na indústria de papel e celulose (ANSCHAU, 2009).

$\mathrm{Na}$ indústria de petróleo e gás sua utilização é em tubos flexíveis onde ocorre a extração de petróleo, resfriadores, tubulações e linhas de distensão, também podendo ser aplicado no armazenamento de produtos químicos (MIRANDA, 2004).

\subsection{Soldagem dos aços inoxidáveis}

Nos aços inoxidáveis a soldabilidade além de garantir resistência mecânica, ductilidade, tenacidade, resistência à fadiga e à corrosão, deve produzir uma soldagem não prejudicial à integridade da região soldada (PAREDES, 2013)

Dentre todos os processos de soldagem, os mais utilizados para a soldagem dos aços inoxidáveis são: SMAW (eletrodo revestido) [ER], GTAW (TIG) e GMAW (MIG/MAG). Nos aços com teor de carbono superior a $0,06 \%$, carbonetos podem ser precipitados com contornos de grão na ZTA, durante o ciclo térmico de soldagem, prejudicando a resistência à corrosão (PAREDES, 2013)

Segundo Paredes (2013), entre os aços inoxidáveis, os aços austeníticos apresentam o risco das trincas de solidificação, o do tipo ferríticos apresentam um crescimento exagerado de grão enquanto, já os aços inoxidáveis martensíticos têm o mesmo tipo de risco que os aços carbono baixa liga. Finalmente, os aços inoxidáveis duplex, contendo 50\% ferrita e 50\% 


\section{(11) 1 ine}

austenita, apresentam um risco de crescimento de grão e também de precipitação de fase sigma e nitreto de cromo.

A soldabilidade dos aços inoxidáveis duplex é boa e parecida com a dos aços inoxidáveis austeníticos da série 300. Este tipo de aço pode-se utilizar a grande maioria dos processos de soldagem, tais como: TIG, MIG, plasma, eletrodo revestido, arame tubular (EUTECTIC CASTOLIN, 2006).

Alguns problemas podem aparecer devido a alterações metalúrgicas ocorridas nas operações de soldagem, porém não detectadas por práticas convencionais (OLIVEIRA, 2013).

O aquecimento da zona fundida (ZF) e da zona termicamente afetada (ZTA) acima de $1200^{\circ} \mathrm{C}$ é comum. Durante o resfriamento dessas regiões, a austenita tende a se formar novamente, porem a velocidade de resfriamento, são relativamente elevadas após o processo de soldagem e a nova quantidade formada de austenita pode não ser suficiente para garantir o bom desempenho do material (OLIVEIRA, 2013)

Segundo Oliveira (2013), o controle dos parâmetros de soldagem é essencial para que a quantidade de austenita desejada seja formada, o controle principalmente de corrente, tensão e velocidade de soldagem, pode influenciar drasticamente que a junta receba a quantidade de calor adequada e que resfrie em condições de temperatura ideais. Também se devem considerar alguns possíveis problemas causados pelo aparecimento de precipitados indesejáveis na microestrutura da junta soldada. Este tipo de fase conhecidas por secundárias (fase sigma, fase chi etc.), podem vir a fragilizar as excelentes propriedades mecânicas e a resistência à corrosão dos aços duplex que se formam durante um resfriamento rápido ou lento da junta soldada (OLIVEIRA, 2013)

\section{MATERIAIS E MÉTODOS}

Para a realização desse estudo utilizou-se uma barra do aço Duplex UNS S31803 e para fins de comprovação da sua composição química foi realizado a análise química em espectrômetro de emissão ótica da marca Spectro.

\subsection{Soldagem}

Para a realização da soldagem, cortou-se a barra em partes para confeccionar os corpos de prova para soldagem.

No procedimento de soldagem utilizou-se o eletrodo E309Mol. A composição química do mesmo está descrita na Tabela 1.

Tabela 1 - Composição química do eletrodo E309 Mol

\begin{tabular}{c|c|c|c|c|c}
\hline $\mathbf{C}(\boldsymbol{\%})$ & $\mathbf{S i}(\boldsymbol{\%})$ & $\mathbf{M n}(\boldsymbol{\%})$ & $\mathbf{C r}(\boldsymbol{\%})$ & $\mathbf{N i}(\boldsymbol{\%})$ & $\mathbf{M o}(\boldsymbol{\%})$ \\
\hline 0,03 & 0,80 & 0,70 & 23,00 & 12,30 & 2,60 \\
\hline
\end{tabular}

Fonte: Esab: Catálogo de consumíveis (2018)

Utilizou-se para soldagem a máquina de solda da marca Lincoln Eletric, modelo S350 Power Wave, e os parâmetros utilizados foram os recomendados pelo fabricante conforme Tabela 2. 


\section{(10ivines}

Tabela 2 - Parâmetros Recomendados pelo fabricante

\begin{tabular}{c|c|c|c}
\hline Eletrodo & Tensão /Tipo de corrente & Diâmetro $(\mathbf{m m})$ & Faixa de Corrente (A) \\
\hline \multirow{2}{*}{309 Mol } & $\begin{array}{c}27-30 \mathrm{~V} \\
\mathrm{CA} \geq 70 \mathrm{~V} \\
\mathrm{CC}+\end{array}$ & 2,5 & $60-90$ \\
\hline
\end{tabular}

Fonte: Esab: Catálogo de consumíveis (2018)

Foram feitos três corpos de provas de Aço Duplex UNS S 31803, com o eletrodo E309Mol. Sendo assim dando dois passes de solda de cada lado em cada corpo de prova.

Logo após os procedimentos de soldagem os corpos de prova foram cortados em tamanhos de espessura de $9 \mathrm{~mm}$, assim transformados em corpos de prova para realização dos ensaios. A Figura 1 mostra o corpo de prova após soldado e cortado.

Figura 1 - Corpo de prova.

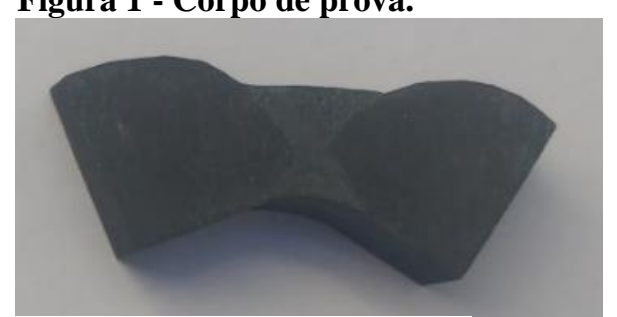

Fonte: Autores deste Trabalho.

\subsection{Tratamento térmico}

Realizou-se os Tratamentos Térmicos em um forno do tipo Mufla, modelo 200F/DM, da marca Fornos Magnus.

Os corpos de prova passaram por dois tipos de tratamentos, um corpo de prova foi submetido a um aquecimento de $600^{\circ} \mathrm{C}$ por um tempo de 2 horas e depois resfriado ao ar. $\mathrm{O}$ outro corpo de prova foi submetido à temperatura de $1050^{\circ} \mathrm{C}$ por 2 horas, resfriado rapidamente na água. Logo depois de submetido a uma temperatura de $600^{\circ} \mathrm{C}$ por mais duas horas e resfriado lentamente ao ar.

Também foi feito mais um corpo de prova que não passou por nenhum tipo de tratamento térmico.

Após os tratamentos térmicos os corpos de prova foram cortados para caberem no molde de embutimento.

\subsection{Preparação das amostras para análise metalográfica}

Depois do corte e dos tratamentos térmicos as amostras passaram pelo procedimento de preparação para a análise metalográfica.

Com as amostras lixadas e polidas, foi realizado o ataque químico, para poder ser realizada a análise das microestruturas. Nesse processo foi utilizado o ataque químico Beraha, que consiste em $20 \mathrm{ml}$ de $\mathrm{HCl}, 100 \mathrm{ml}$ de $\mathrm{H}_{2} \mathrm{O}$ e $0,5 \mathrm{~g}$ de Metabisulfito de Potássio. O ataque foi realizado por imersão e as amostras foram secas com auxílio de ar quente (soprador de ar). 


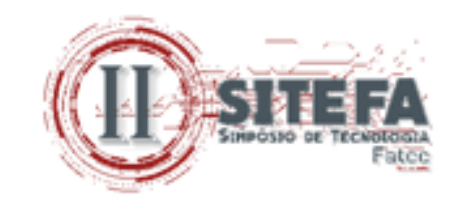

\subsection{Microdureza Vickers}

Realizou-se a medição da microdureza Vickers ao longo da superfície das amostras, passando pelo metal base (MB), pela zona termicamente afetada (ZTA) e pela zona fundida (ZF), com carga de 9.8N em microdurometro tipo MHV 2000.

\section{RESULTADOS E DISCUSSÃO}

Essa seção destina-se aos resultados e discussões, apresentados nas subseções a seguir.

\subsection{Análise química}

Obteve-se como resultado da análise química a composição descrita na Tabela 3, onde se pode comprovar que as porcentagens dos elementos químicos estão de acordo com o esperado para o aço duplex UNS 31803.

Tabela 3 - Resultado da Análise Química realizada na amostra do aço duplex.

\begin{tabular}{l|l|l|l|l|l|l|l|l|l}
\hline $\boldsymbol{C}(\%)$ & $\mathbf{S i}(\%)$ & $\mathrm{Mn}(\%)$ & $\mathbf{C r}(\%)$ & $\mathbf{M o}(\%)$ & $\mathbf{N i}(\%)$ & $\mathbf{C u}(\%)$ & $\mathrm{Nb}(\%)$ & $\mathrm{V}(\%)$ & $\mathrm{Fe}(\%)$ \\
\hline $\mathbf{0 , 0 3 4 3}$ & $\mathbf{0 , 7 7 4}$ & $\mathbf{1 , 0 5}$ & $\mathbf{2 3 , 5 2}$ & $\mathbf{3 , 2 7}$ & $\mathbf{5 , 9 7}$ & $\mathbf{0 , 4 6 5}$ & 0,0055 & 0,0501 & 64,7 \\
\hline
\end{tabular}

Fonte: autores deste trabalho (2019)

\subsection{Análise metalográfica}

A Figura 2(a) mostra a microestrutura do aço duplex como recebido, a Figura 2(b) a microestrutura do metal base (M.B.) após o tratamento térmico a $600^{\circ} \mathrm{C}$ resfriado ao ar e a Figura 2(c) a microestrutura do metal base após o tratamento térmico a $1050^{\circ} \mathrm{C}$.resfriado em agua, e aquecido novamente a $600^{\circ} \mathrm{C}$ e resfriado ao ar.

Figura 2 - (a) M.B. sem tratamento; (b) M.B. tratado a $600^{\circ} \mathrm{C}$; (c) M.B. tratado a $1050^{\circ} \mathrm{C}$.
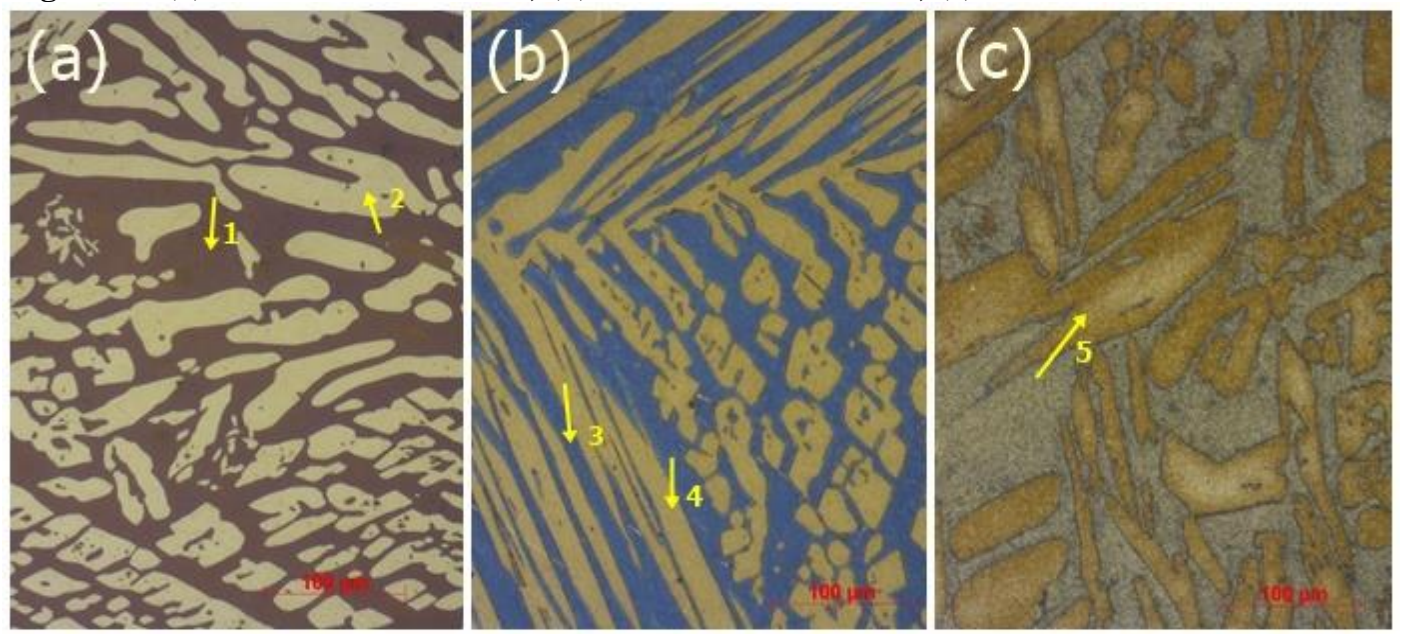

Fonte: autores deste trabalho (2019)

Observa-se na figura 2(a) a morfologia e distribuição de fases com placas de austenita numa matriz ferrítica, onde a fase marrom escura é a fase ferrita (1), e a fase bege é a fase 


\section{(1010men}

austenita (2), revelando assim uma microestrutura típica de aços inoxidáveis duplex, com iguais proporções de fases ferrita e austenita.

A microestrutura da Figura 2(b) mostra que não foi verificada nenhuma modificação na microestrutura do material estudado quando submetido às temperaturas de envelhecimento a $600{ }^{\circ} \mathrm{C}$, apresentando uma matriz de ferrita (4) e austenita similar à estrutura da amostra em condição de recebimento. Houve somente um alongamento da fase austenítica (3) quando comparada com a condição de como recebido, mas que não se observa em toda microestrutura do material.

E na Figura 2(c) mostra uma variação da microestrutura austenítica (5) entre placas pequenas e grandes, e também de grãos poligonais, decorrentes do tratamento térmico que foi aplicado na amostra. Não foi observado a presença de fase sigma nas condições de análise por microscopia ótica.

A Figura 3(a) mostra a zona fundida (ZF) sem tratamento e a Figura 3(b) mostra a região compreendida entre a zona fundida e a zona termicamente afetada pelo calor (ZTA) do corpo de prova soldado com eletrodo E309 Mol.

Figura 3 - (a) Zona Fundida E309 sem tratamento. (b) Solda/ZTA E309 Mol sem tratamento
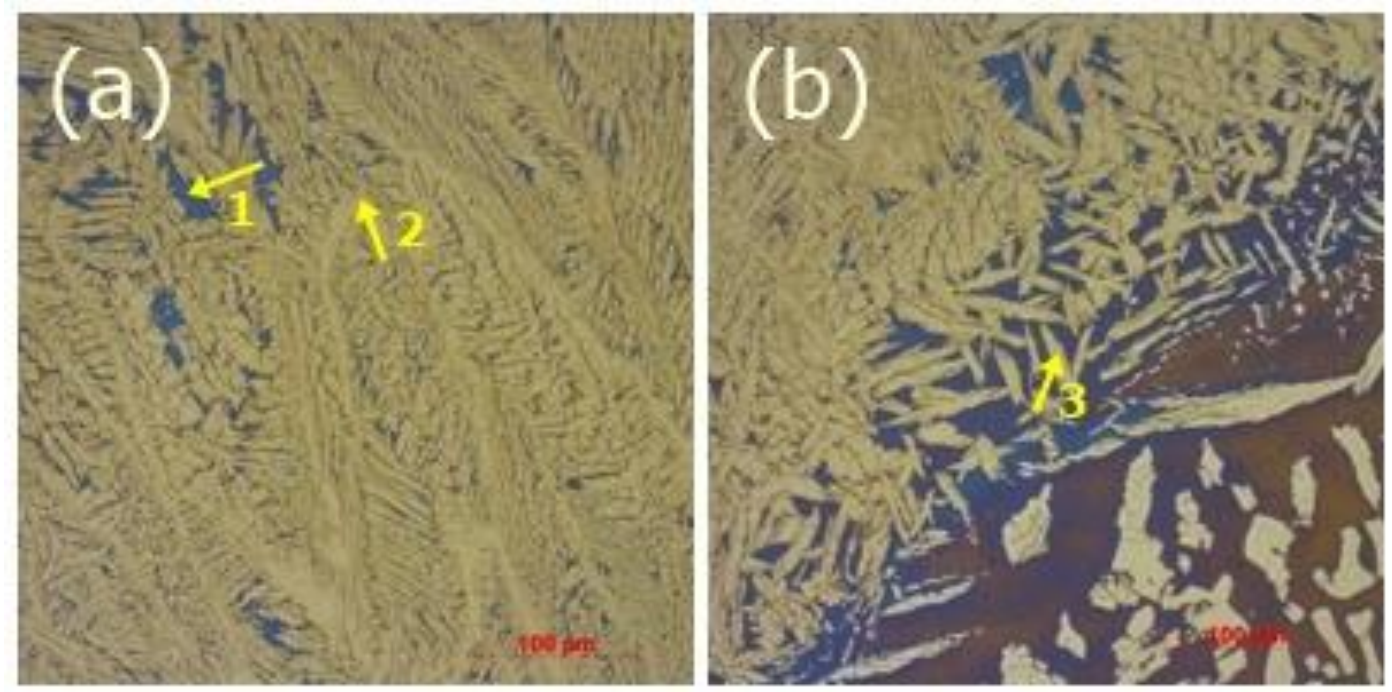

Fonte: autores deste trabalho (2019)

A microestrutura observada na zona fundida (Figura 3(a)) consiste em austenita de grãos colunares e austenita de Widmanstatten (1), além de uma pequena quantidade de ferrita (2) (fase azul) típica de eletrodos austeníticos como o E309 Mol.

$\mathrm{Na}$ região compreendida entre a ZF e a ZTA (Figura 3(b)) nota-se a presença de austenita intergranular (3) ocasionada pela diluição do metal base com o metal de adição, além da velocidade de resfriamento que proporciona a transformação da ferrita em austenita intergranular. Nota-se também uma variação da microestrutura austenítica provocada pelo ciclo térmico durante a soldagem.

A figura 4(a) mostra a Zona fundida e a Figura 4(b) mostra a solda/ZTA do corpo de prova soldado com eletrodo $\mathrm{E} 309$ tratado a $600^{\circ} \mathrm{C}$ resfriado ao ar. 


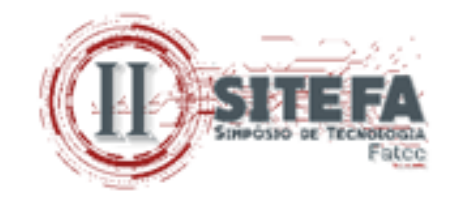

Figura 4 - (a): Zona Fundida E309 Mol, tratado a $600{ }^{\circ}$ C. (b) Solda ZTA E309 Mol, tratado a $600{ }^{\circ} \mathrm{C}$ ( Aumento de $200 \mathrm{x}$ )
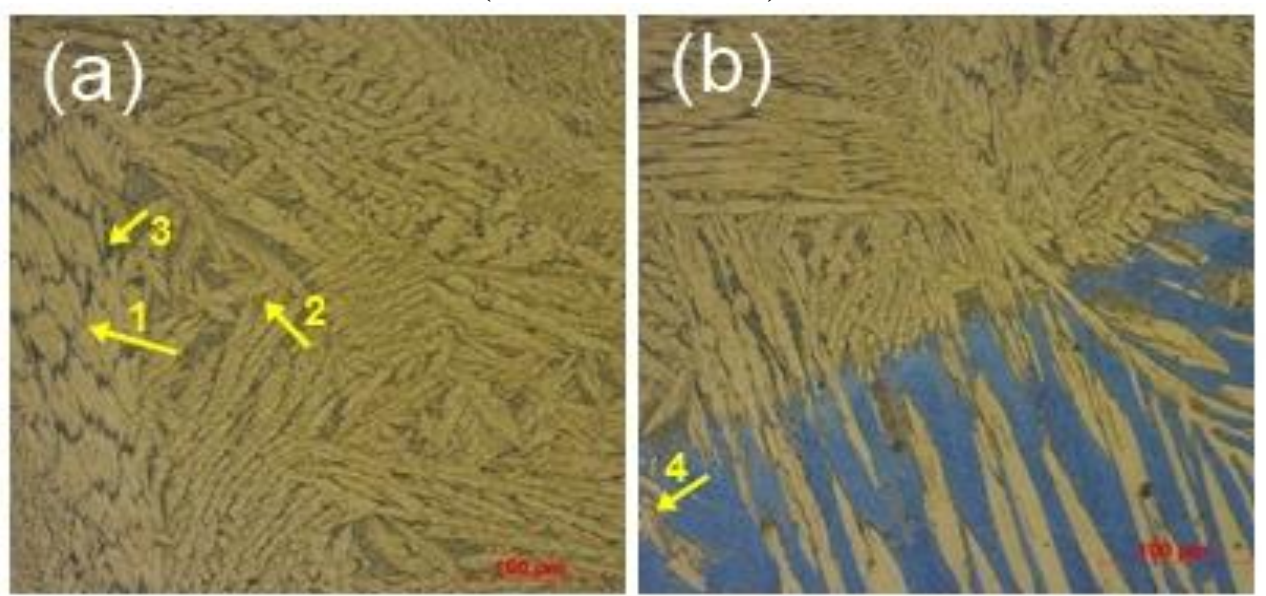

Fonte: autores deste trabalho (2019)

A microestrutura observada na zona fundida (Figura 4(a)) consiste em austenita de grãos colunares (1) e austenita de Widmanstatten (2). Quase não se vê a ferrita (fase azul) (3) na região fotografada, pois esta fase fica entre 5 e $10 \%$ durante o resfriamento da ZF. Não se nota nenhuma variação microestrutural decorrente do tratamento térmico.

Na região compreendida entre a ZF e a ZTA (Figura 4(b)) nota-se também a presença de austenita intergranular ocasionada pela diluição do metal base com o metal de adição, e também um aumento da relação austenita/ferrita na microestrutura. Esta variação é provocada pelo ciclo térmico que acontece durante a soldagem.

A Figura 5(a) mostra a zona fundida e a figura 5(b) mostra a ZF/ZTA do corpo de prova soldado com eletrodo $\mathrm{E} 309 \mathrm{Mol}$ tratado a $1050^{\circ} \mathrm{C}$, resfriado em água, aquecido novamente a $600^{\circ}$ e resfriado ao ar.

A microestrutura da zona fundida (Figura 5(a)) consiste em austenita de grãos colunares (1) e austenita de Widmanstatten (2) e de ferrita (3) (fase azul) mais distribuída na microestrutura. Esta maior distribuição deve-se principalmente ao tratamento térmico em alta temperatura, que homogeneizou melhor a microestrutura.

Figura 5 - (a): Zona Fundida E309 tratado a $1050^{\circ}$ C. (b): ZTA/Solda E309 Mol tratado a $1050{ }^{\circ} \mathrm{C}$ ( Aumento de $200 \mathrm{x}$ )
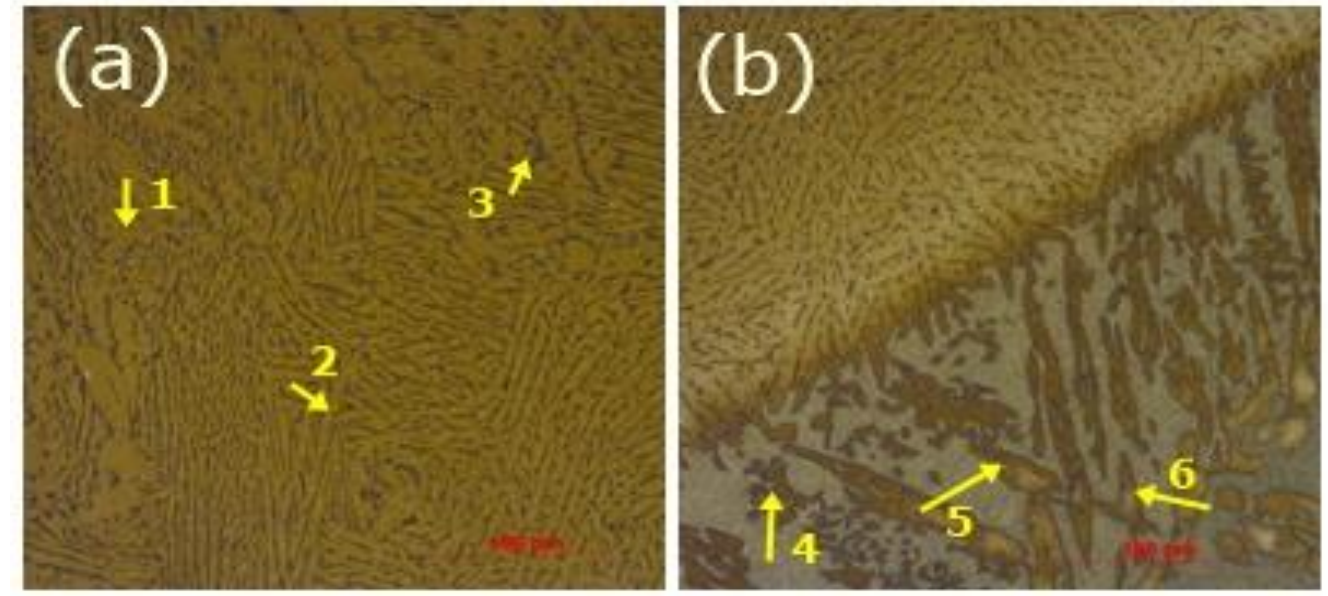

Fonte: autores deste trabalho (2019) 


\section{(iil) $\sin : \frac{1}{1}$}

Na região compreendida entre a ZF e a ZTA (Figura 5(b)) nota-se também a presença de austenita intergranular (4) ocasionada pela diluição do metal base com o metal de adição, e também uma variação da microestrutura austenítica entre placas pequenas e grandes (5), e também de grãos poligonais (6), que podem ter sido modificadas pelo tratamento térmico, mas que também é provocada pelo ciclo térmico que acontece durante a soldagem.

\subsection{Ensaio de microdureza Vickers}

Observa-se na Tabela 4, as medidas de microdureza dos corpos de prova soldados.

Tabela 4 - Resultados obtidos pelo ensaio de Microdureza Vickers

\begin{tabular}{cccc}
\hline & ST & $\mathbf{6 0 0}$ & $\mathbf{1 0 5 0}$ \\
\hline MB & 238,1 & 233,9 & 233,5 \\
MB & 235,8 & 231,6 & 233,1 \\
ZTA & 276,8 & 251,5 & 246,1 \\
ZTA & 275,4 & 250,4 & 244,3 \\
ZTA & 273,1 & 251,1 & 246,1 \\
ZF & 243,2 & 232,4 & 216,6 \\
ZF & 246,1 & 234,8 & 217,6 \\
ZF & 245,5 & 230,5 & 216,1 \\
ZTA & 275,1 & 254,4 & 247,4 \\
ZTA & 269,2 & 252,6 & 243,6 \\
ZTA & 271,5 & 251,3 & 245,2 \\
MB & 240,4 & 237,4 & 239,8 \\
MB & 239,1 & 236,4 & 235,8 \\
\hline
\end{tabular}

Fonte: autores deste trabalho (2019)

Conforme dados obtidos na Tabela 4 e para uma melhor análise dos resultados, foram gerados gráficos que mostram um comparativo entre os resultados obtidos nas três condições de estudo com o eletrodo E309 Mol.

O gráfico 1 mostra o comparativo entre as durezas obtidas para as amostras soldadas com o eletrodo E309 Mol.

Gráfico1 - comparativo das microdurezas entre as amostras soldadas com o E309 Mol

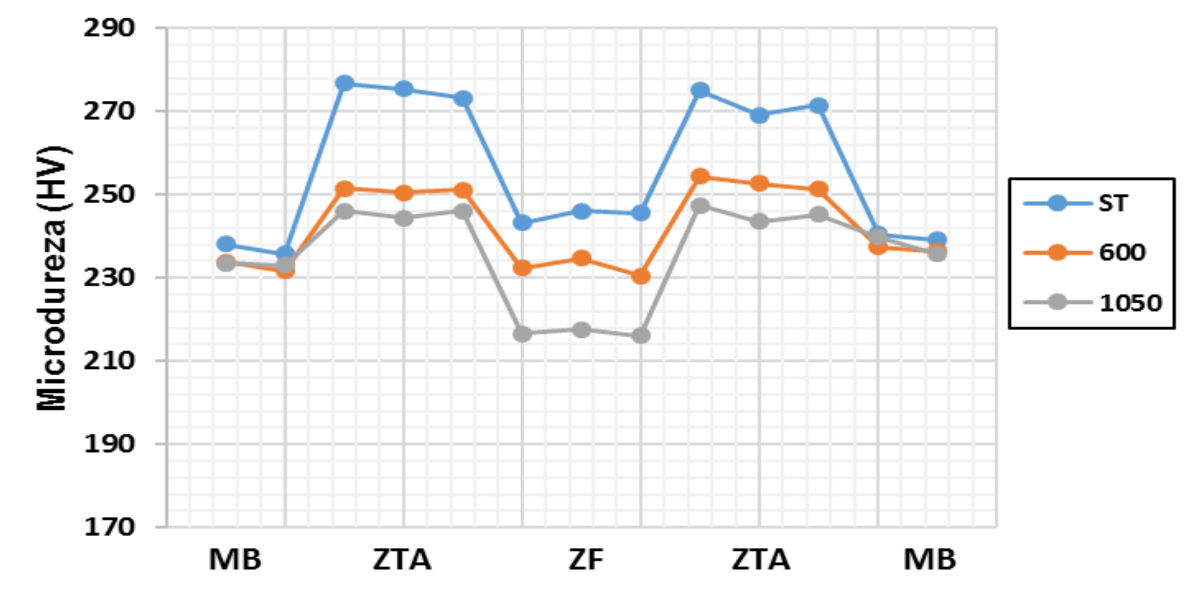

Fonte: autores deste trabalho (2019) 


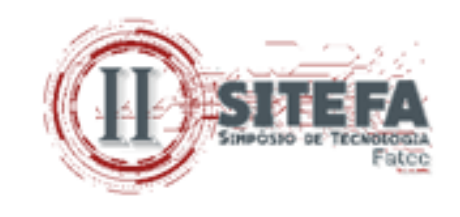

Nota-se na figura acima que a dureza do metal base não teve variação significativa após a realização dos tratamentos térmicos quando comparada com o mesmo sem tratamentos. Nas zonas termicamente afetadas, foi notado variação significativa, quando as amostras foram submetidas aos tratamentos térmicos. A variação de dureza na zona fundida das amostras em estudo, teve uma diminuição quando a amostra foi tratada a $1050^{\circ} \mathrm{C}$, seguidas da amostra tratada a $600^{\circ} \mathrm{C}$, em relação às amostras sem tratamento.

\section{CONCLUSÃO}

Com base nos resultados apresentados conclui-se que:

1. O tratamento térmico a $600^{\circ} \mathrm{C}$ não provocou mudanças microestruturais visíveis por microscopia ótica, mas obteve variações significativas de dureza na ZF e na ZTA.

2. O tratamento térmico a $1050^{\circ} \mathrm{C}$ observou-se uma homogeneização na microestrutura e apresentou variações significativas de dureza na ZF. A maior variação ocorre quando comparado o tratamento a $1050^{\circ} \mathrm{C}$ e sem tratamento. Entretanto para os tratamentos entre si, houve uma pequena diminuição da dureza na ZF quando comparadas.

\section{REFERÊNCIAS}

ANSCHAU, L.S.N. Avaliação quantitativa das fases presentes no aço inoxidável duplex UNS S32304, Vitória, 2009, 46p.

ESAB, Catálogo de consumíveis. 2018. Disponível em: https://www.esab.com.br/br/pt/support/documentation/upload/catalogo-consumiveis-esab.pdf. Acesso em: 07 set. 2018.

EUTECTIC CASTOLIN. Aços inoxidáveis. 2006. Disponível em: http://www.eutectic.com.br/catalogos/catalogo-inox.pdf. Acesso em: 07 set. 2018.

LOUREIRO, J. P. Caracterização do Aço Inoxidável Duplex UNS S31803 pela técnica não destrutiva de correntes parasitas pulsadas. Rio de Janeiro, 2010. 102 p.

MAGNABOSCO, R. Influência da microestrutura no comportamento eletroquímico do aço SAF 2205. Tese (Doutorado em Engenharia) - Departamento de Engenharia Metalúrgica e de Materiais, Universidade de São Paulo, São Paulo -SP, 2001. 181 p.

MIRANDA, M. A. R. Quantificação das fases austeníticas e ferríticas no aço inoxidável duplex submetido a vários tratamentos térmicos. Tese (Mestrado em Física) Departamento de Física, Universidade Federal do Ceará, Fortaleza - CE, 2004.

OLIVEIRA, L. A. Influência Do Metal De Adição Na Susceptibilidade À Corrosão Sob Tensão De Juntas Soldadas Dissimilares De Aço Inoxidável Austenítico 316 E Aço Inoxidável Dúplex 2304, Itajubá, 2013, 80p. 
PAREDES, R.S.C. Soldagem de Aços Inoxidáveis - Conceito de soldabilidade. 2013.

Disponível em:

http://ftp.demec.ufpr.br/disciplinas/EME733/Arquivos\%20da\%20disciplina/Previs_o\%20da\% 20Soldabilidade $\% 20$ dos $\% 20 \% 20$ A_os\%20Inoxid_veis\%20P_s\%20(1.1).pdf. Acesso em: 10 set. 2018

SILVA, E. M., Estudo da Correlação entre o aporte térmico, as propriedades magnéticas e a corrosão sob tensão em juntas soldadas de aço inoxidável ferrítico AISI-409. Tese de doutorado- Universidade Federal de Itajubá, Itajubá, 2011.

UBINOX. Coletânea de informações técnicas - Aço Inoxidável. Disponível em:

http//:www.abinox.org.br/upfiles/arquivos/biblioteca/tipos-de-acos-inoxidaveis.pdf. Acesso em: 29 de março. 2018. 